\title{
EFFECTS OF RIVER BANK SOIL PHYSICAL AND CHEMICAL FACTORS ON POPULUS PRUINOSA SCHRENK CLONAL GROWTH
}

\author{
GAI, Z.. - LI, X." - ZHAI, J. - CHEN, X. - LI, Z.* \\ College of Plant Sciences, Tarim University, Alar 843300, China \\ Key Laboratory of Biological Resource Protection and Utilization of Tarim Basin, Xinjiang \\ Production and Construction Group, Alar 843300, China \\ Desert Poplar Research Center of Tarim University, Alar 843300, China \\ ${ }^{\#}$ These authors contributed equally to this study. \\ *Corresponding author \\ e-mail: lizhijun0202@126.com; phone: +86-997-468-1202 \\ (Received $13^{\text {th }}$ Feb 2020; accepted 22 ${ }^{\text {nd }}$ May 2020)
}

\begin{abstract}
In this study, soil physical and chemical factor changes before and after flooding and the effects of such changes on the clonal regeneration of Populus pruinosa Schrenk were investigated. The results show that soil moisture content and field water capacity had the greatest direct effect on the clonal growth of $P$. pruinosa before flood overtopping. Soil porosity had the greatest direct effect after flood overtopping. Soil organic matter content and alkaline nitrogen had the greatest direct effect on the clonal growth of $P$. pruinosa before flood overtopping. Available phosphorus and available potassium had the greatest direct effect after flood overtopping. The flooded woodland was conducive to clonal growth of $P$. pruinosa, but flood overtopping for too long led to increased soil bulk density, decreased porosity, and increased soil salinity, all of which hindered clonal growth. We suggest the implementation of flood diversion measures in flooding woods to ensure normal post-flooding clonal growth. Meanwhile, water retained in the soil after flooding would also be available to promote clonal growth the following spring. These may be of great significance for increasing the benefits of seasonal flooding in this arid area.
\end{abstract}

Keywords: clonal ramets, soil nutrient, flood overtopping, desert riparian, population regeneration

\section{Introduction}

Clonal plants exhibit a clonal growth habit. Such plants colonise reproductive organs, including buds, by tillering or by propagation from the branches of maternal ramets to produce vegetative propagated plants (propagules). Propagules develop into potentially independent offsprings (clonal ramets) that are connected to maternal ramets and eventually form a group of interconnected clonal plants (Alpert, 1996). Under natural conditions, clonal plants produce clonal ramets with potentially independent survival abilities that can undergo widespread horizontal and vertical vegetative growth that characterises the clonal growth observed in fields (Silvertown, 1984). Therefore, individual ramets of clonal plants morphologically and physiologically develop and increase their territories through clonal growth. Ultimately, clonal growth allows a genetically identical group of cloned plants to occupy a considerable habitat area while concurrently increasing the number of plant populations engaging in interspecies competition (Zhang and Wang, 2005).

In arid and semi-arid areas, soil moisture is the dominant ecological factor affecting plant growth. Plants respond to soil water conditions through phenotypic plasticity. For clonal plants, the response is reflected not only by their clonal growth characteristics but 
also in their clonal morphological characteristics (such as the distribution pattern of individual ramets and individual morphological changes), which are closely related to the ecological adaptations and resource acquisition of plant populations (Luo and Dong, 2002). Previous studies have shown that clonal plants have strong phenotypic plasticity under various soil conditions whereby clonal plant growth and morphology may exhibit strong phenotypic diversity. Moreover, the mechanisms, degree, and trends of phenotypic plasticity may vary among different plants (He et al., 2007). For the number of ramets, some studies have shown that with increased available soil moisture, the number of clonal ramets of Hippophae rhamnoides Linnaeus and Leymus secalinus (Georgi) Tzvelev significantly increased (He et al., 2007; Ren, 1999). Moreover, the height and biomass of the population have been observed to increase with high soil moisture (He et al., 2007).

The heterogeneous distribution of soil nutrients also affects the changes in growth characteristics of clone plants. Such changes further influence the spatial distribution patterns and clonal plasticity of the plant components of an entire clonal plant or even of an entire plant population. The size of clonal plants has been demonstrated to change in response to changing soil nutrient availability, as reflected by the biomass of both a population and its components, including the average basal diameter, average plant height, and allocation of aboveground biomass (Bai et al., 2019; Heng, 2002; Pan et al., 2005; Yue et al., 2002). In a high-quality habitat (low salt, high light, and high nutrient levels), Scirpus olneyi rhizome ramets have been shown to spread clearly into a population of many densely distributed short-rhizome clonal ramets. Conversely, in a low-quality habitat (high salt, low light, and low nutrient levels) many sparsely distributed clonal ramets have been shown to emerge (Ikegami et al., 2007). Roiloa et al. (2006) reported similar results for Fragaria vesca and proposed that more ramets were distributed in high-quality patches within a heterogeneous habitat. In a different study, Vallisneria spiralis L. was also reported to exhibit more growth in a heterogeneous habitat, as reflected by longer leaves and larger sizes observed in patches with higher nutrient levels (Hodge, 2004).

Populus pruinosa and the related species Populus euphratica are members of the Salicaeae family. $P$. pruinosa achieves reproduction and regeneration by the development of adventitious buds on underground horizontal lateral roots, which develop into clonal ramets to maintain the desert riparian forest population ( $\mathrm{Li}$ et al., 2012; Zheng et al., 2016a). Previous researches showed that the density of clonal ramets of $P$. euphratica was markedly influenced by light and soil conditions (water and nutrients) (Wu et al., 2008). Soil structure was also observed to play a decisive role in the emergence of clonal ramets, which were observed only after buds on the lateral root penetrated a certain thickness of the soil layer. Consequently, if the soil structure is too tight, it is difficult for a bud to form a ramet. Therefore, loose soil facilitates the formation of clonal ramets (Zhang et al., 2007). Meanwhile, one study demonstrated that a $15 \%$ soil water content was the optimum moisture content for P. euphratica root germination (Jing et al., 2013), in agreement with a study of $P$. pruinosa woodland forest far from a river, where clonal growth was observed only in the presence of $15 \%$ soil moisture content or higher (Zheng et al., 2016b). A later study showed that with increased soil moisture content, the numbers of adventitious buds and unearthed and earthed ramets significantly increased, indicating that soil moisture was an important factor affecting the growth of poplar clones (Zheng et al., 2016a). In addition, the number of adventitious buds, underground ramets and unearthed ramets in the forest was significantly lower than that in the forest edge, in the 
forest edge, the number of adventitious buds was close related to the content of soil organic matter, alkali nitrogen and available potassium, and there was also a significant correlation between the underground ramets and the content of soil alkali nitrogen and available phosphorus, indicating that soil fertility also was an important factor affecting the growth of poplar clones (Zheng et al., 2019).

Although flood overtopping causes changes in P. pruinosa forest soil physical and chemical factors, it is still unclear how such soil physical and chemical factor changes affect clonal growth of $P$. pruinosa throughout the growing season. These effects must all be understood to determine the impact that flooding has on the clonal growth of $P$. pruinosa with specific regard to clonal reproduction and regeneration. The goals of this study are to (1) reveal the dynamic variation in the numbers of adventitious buds, unearthed/earthed clonal ramets, and growth rates of ramets of $P$. pruinosa before and after flooding; (2) uncover the dynamic changes in both physical and chemical soil factors before and after flooding; and (3) clarify the relationship between clonal growth dynamics of $P$. pruinosa and dynamic changes in soil physical and chemical factors to assess the impact of flooding on riparian forest $P$. pruinosa clonal reproduction and regeneration. The results of this study should provide a theoretical basis for effectively utilizing flood overflow to promote clone reproduction and regeneration of $P$. pruinosa.

\section{Materials and methods}

The study was conducted in a natural woodland of $P$. pruinosa on the Tarim River in Xinjiang in northwest China, located at $80^{\circ} 50^{\prime} \mathrm{E}, 40^{\circ} 29^{\prime} \mathrm{N}$. A few accompanying herbaceous or shrub plants, such as Tamarix chinensis Lour., Glycyrrhiza uralensis Fisch, Phragmites australis (Cav.) Trin. Ex Steud., and Aeluropus sinensis, also commonly grow in these woodlands. Annual river floods are known to expand into the woodland near river banks when flood overtopping occurs. For example, woodland was flooded during the flood overtopping that occurred from July 25 to August 18 of 2014 and again from July 26 to August 21 of 2015.

Three sample plots were studied in parallel, each $30 \mathrm{~m} \times 30 \mathrm{~m}$ in size and located within a vertical height of $200 \mathrm{~m}$ above the river. All plots were fenced to protect them from sheep grazing (Fig. 1). Clone growth indexes were surveyed, and soil samples were collected every 20 days from April early August in both 2014 and 2015; From the beginning of August to the end of September, the investigation was conducted once a month due to the difficulty caused by surface water after flooding; The survey was conducted on 20 days from the end of September to the end of October.

In each survey, 10 clonal ramets were randomly dug up from each sample plot. For each unearthed ramet, the horizontal lateral root on either side was identified as either the proximal end root (the clonal ramet root portion closer to the mother plant) or the distal end root (the clonal ramet root portion further from the mother plant). Both ends encompassed a total root length span of $2.5 \mathrm{~m}$ symmetrically spanning both sides of the clonal ramet. The point on a lateral root at which the clonal ramet emerged, defined as the middle of the lateral root, was defined as the middle of the $50-\mathrm{cm}$ central root segment. Horizontal lateral roots were then divided into four segments, two $50-\mathrm{cm}$ segments adjacent to the proximal end of the central root segment and two $50-\mathrm{cm}$ segments adjacent to the distal end of the central root segment. Thus, five segments were selected along each root over a total length of $2.5 \mathrm{~m}$ (defined as the unit length). The depth of each root segment was measured to 
determine its soil profile. Surveys of the numbers of adventitious buds and unearthed/earthed clonal ramets along each unit length of horizontal lateral root were conducted. At the same time, the number of ramets in each cluster, ramet height, and ramet basal diameter of all ramets in each plot were also measured.

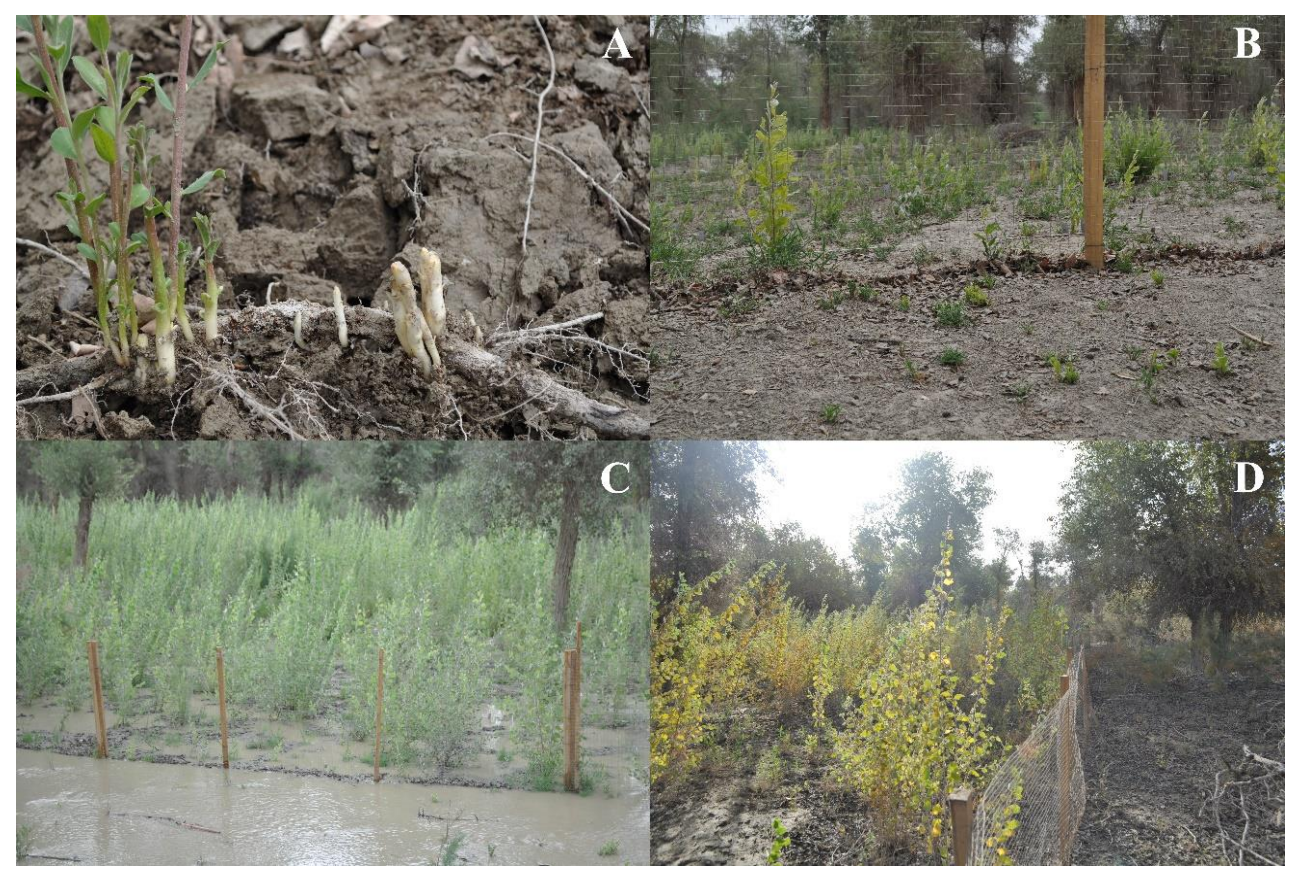

Figure 1. Growth of clone plants of P. pruinosa before and after flood overtopping. (A) clonal plants of $P$. pruinosa, $(B)$ the experimental sites of clone plants of $P$. pruinosa, $(C)$ woodland was flooded during the flood overtopping and $(D)$ the growth of clone plants after flood overtopping

Collection and analyses of soil samples were performed to determine soil physical and chemical characteristics. Each survey was performed at the time of digging to assay each unit length of horizontal lateral root. Soil samples were also excavated at the point of emergence of each clonal ramet to construct a soil profile within a square area of $1 \mathrm{~m}$ $\times 1 \mathrm{~m}$ around the ramet emergence point. Within this sampling area, soil samples at $20 \mathrm{~cm}, 40 \mathrm{~cm}$, and $60 \mathrm{~cm}$ depths were collected and analysed.

Soil moisture was determined using a previously reported oven-drying method, soil bulk density, porosity, and field capacity were determined using samples collected using a cutting ring (ring knife) and analysed in the laboratory (Zhao, 2015). Soil pH was measured using the potentiometric method. Soil total salt was measured using the gravimetric extraction method, whereby soil samples were mixed with water in a known ratio and mixed by oscillation for a specific period of time, followed by extraction of soluble salt from the liquor by filtration. The filtrate was tested in liquid form to determine soil water-soluble salts and other chemical characteristics. Soil organic matter content was determined using a potassium dichromate-based method in combination with a heating method (Wei et al., 2015). Alkaline nitrogen was determined using the alkaline hydrolysis diffusion method (Wei et al., 2015). Available phosphorus was determined using the sodium bicarbonate method (Ren et al., 2015), and available potassium was determined using the ammonium acetate-flame photometer method (Ren et al., 2015). 
The computational formulas are as follows:

$$
\begin{aligned}
& \text { Soil moisture content }=\frac{\text { mass of aluminium box and soil sample before baking }- \text { mass of aluminium box and soil after baking }}{\text { mass of aluminium box and soil sample after baking }- \text { mass of empty aluminium box }} \times 100 \% \\
& \text { Soil bulk density }=\frac{\text { dry soil mass in ring knife }}{\text { ring knife volume }} \\
& \text { Soil porosity }=\frac{1-\text { soil bulk density }}{2.65} \times 100 \% \\
& \text { Field capacity }=\frac{\text { wet soil weight }- \text { dry soil weight }}{\text { dry soil weight }} \times 100 \%
\end{aligned}
$$

\section{Data analysis}

The data was entered into an Excel table, and the average value of each factor was calculated using the size of the average drawing. A one-way ANOVA was conducted on the variance in clonal growth and soil physical and chemical factors (at level of $\alpha=0.05$ ). Path analysis used by SPSS 15.0 was applied to calculate the effect of soil physical and chemical factors on the growth of clones.

\section{Results}

\section{Dynamic variation patterns of Populus pruinosa clonal growth}

In 2014 and 2015, the Tarim River flood overtopped the riparian forest on July 25 and July 28, respectively. Using the late July flood overtopping date as the reference time node, clonal growth characteristics at the forest edge both before and after flood overtopping were determined. The result shows that the number of adventitious buds and earthed clonal ramets from late April to early June increased gradually (Fig. 2A) and the numbers of them from late June to late October decreased gradually (Fig. $2 B$ and Table $A 1$ in the Appendix). The number of unearthed clonal ramets exhibited gradually decreasing trends before and after flood overtopping in both years, there was a significant difference in the number of unearthed clonal ramets in late April and late October - the total numbers before flood overtopping was higher than that after flood overtopping (Fig. 2C). The growth rate of ramets height from late April to late June increased gradually and that from early August to late October decreased gradually (Fig. 2D). The growth rate of ramets height was significantly different among the four time points $(4 / 27$, $6 / 29,8 / 5,10 / 21)$. The growth rate of clonal ramets basal diameter from late April to late June increased gradually and that from middle July to late October decreased gradually (Fig. 2E). The number of per cluster ramet from late April to late June increased gradually and that from early August to late October decreased gradually (Fig. 2F). It was also significantly different among the four time points $(4 / 27,6 / 29,8 / 5,10 / 21)$.

Overall, the period from late April to late June before flood overtopping is a period of fast $P$. pruinosa clonal growth, the number of adventitious buds, earthed clonal ramets and per cluster ramet in July were significantly decreased, which may be related to the significant reduction of soil moisture content from late June to late July (Fig. 3A). In different years, the trends of clone reproductions of $P$. pruinosa is consistent, but the clone growth of the same period is different. 

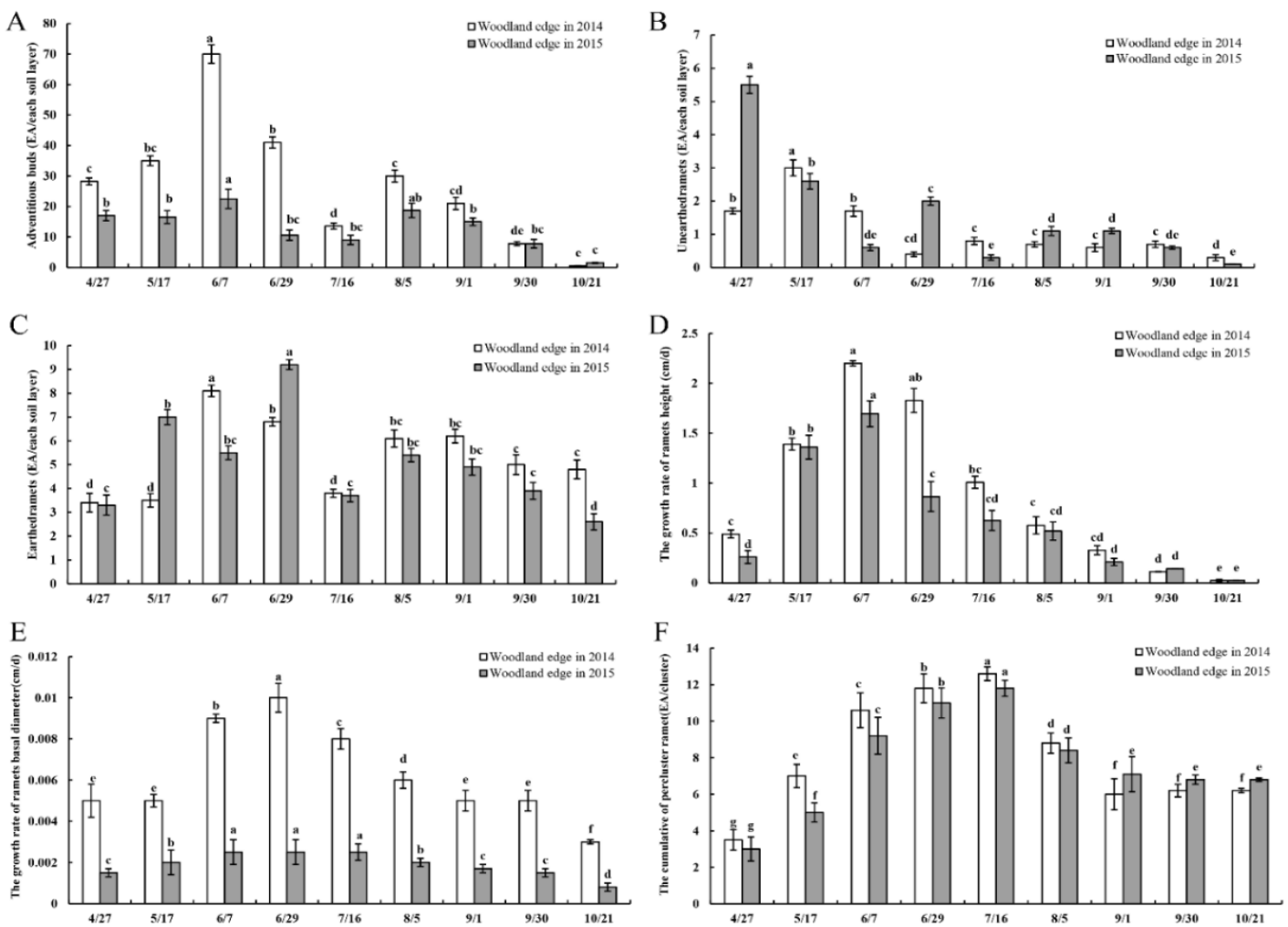

Figure 2. Dynamic variation in P. pruinosa clonal growth before and after flood overtopping.

(A) The number of adventitious buds, (B) the number of unearthed clonal ramets, $(C)$ the number of adventitious buds and earthed clonal ramets, $(D)$ the growth rate of ramets hight, $(E)$ the growth rate of ramets basal diameter and $(F)$ the cumulative of per cluster ramet

\section{Dynamic variation patterns of soil physical factors}

The results showed that the change trends of soil moisture content, field capacity, soil bulk density and soil porosity were almost consistent in 2014 and 2015 (Fig. 3; Table A2). The soil moisture content significantly increased in August after flood overtopping and then later declined gradually to reach minimum values by late October each year, but the soil moisture content was higher after the flood than before (Fig. 3A). Field capacity values all exhibited an a very gradual decreasing trend from April to midJuly (just before flood overtopping), and the field capacity in August significantly increased above July levels, and then remain consistent (2015) or decreased gradually (2014) (Fig. 3B). The soil bulk density and soil porosity in August after flood overtopping exhibited the gradually increasing and decreasing trends, respectively (Fig. 3C and 3D). The results showed that the change trends of soil moisture content, field capacity, soil bulk density and soil porosity were inconsistent before and after flood overtopping.

\section{Dynamic variation patterns of soil chemical factors}

The results showed that the change trends of soil organic matter, alkaline nitrogen, available phosphorus, available potassium, total salt content and $\mathrm{pH}$ values were almost consistent in 2014 and 2015 (Fig. 4; Table A3). The contents of soil organic matter (Fig. 4A). and the alkaline nitrogen (Fig. 4B). from late April to middle July before 
flood overtopping exhibited the trends of increasing first and then decreasing, and the contents of them from late August to late October after flood overtopping decreased gradually.
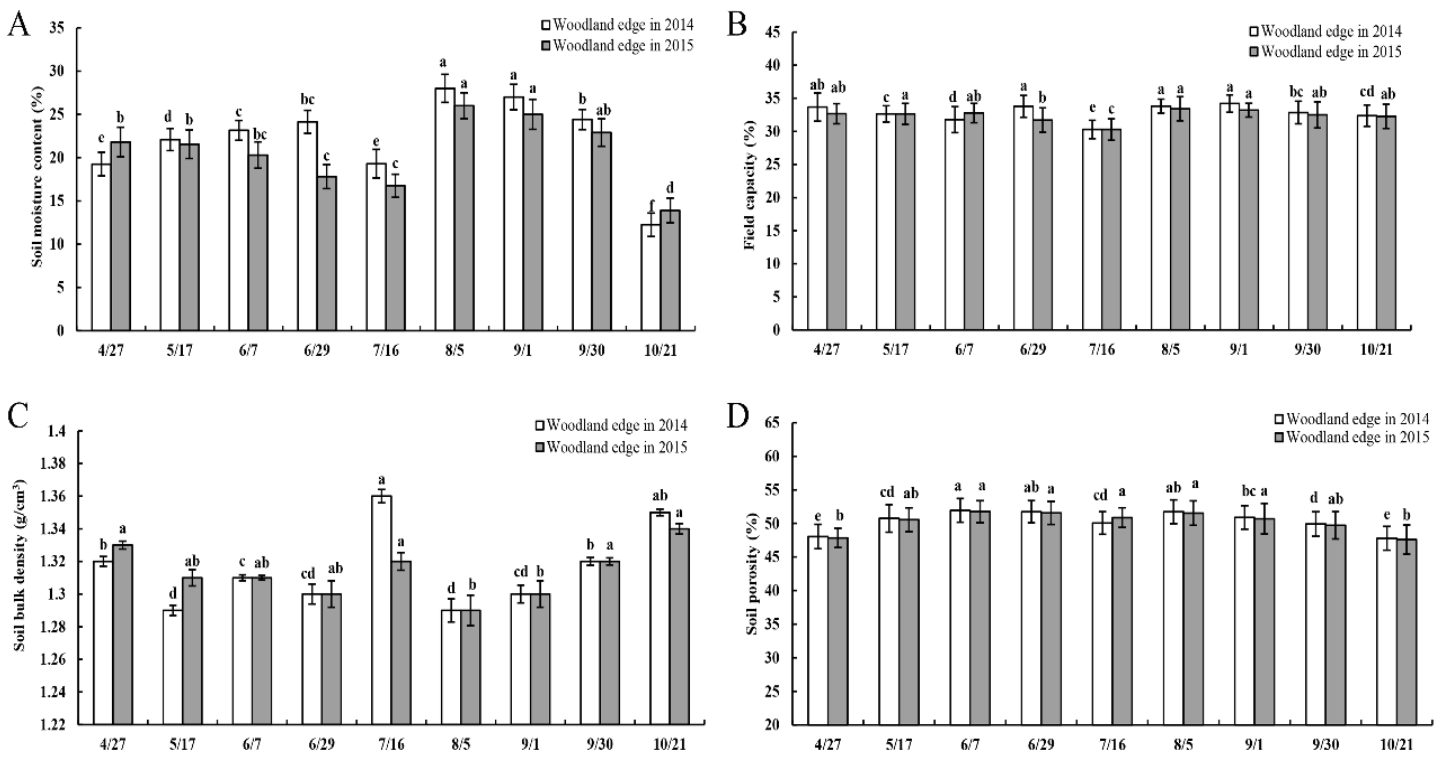

Figure 3. The dynamic change in soil physical factors before and after flood overtopping. (A) Soil moisture content (Eq. 1), (B) field capacity (Eq. 4), (C) soil bulk density (Eq. 2) and (D) soil porosity (Eq. 3)

The content of soil available phosphorus from late April to middle July before flood overtopping exhibited the trends of increasing first and then decreasing, the content of soil available phosphorus decreased to its lowest value in August and it from late August to late October after flood overtopping increased gradually (Fig. 4C). The content of soil available potassium remained at its highest level for the entire growing season from late April to late June and then significantly decreased in the middle of July, it from late August to late October after flood overtopping increased gradually (Fig. 4D). The content of total salt (Fig. 4E) and pH values (Fig. 4F) from late April to middle July before flood overtopping exhibited gradually the trends of decrease and the content of them from late August to late October after flood overtopping showed gradually the trends of increase, the significant difference were observed among the four time points $(4 / 27,7 / 16,8 / 5,10 / 21)$. The results showed that the change trends of soil organic matter, alkaline nitrogen, available phosphorus, available potassium, total salt content and $\mathrm{pH}$ values were inconsistent before and after flood overtopping.

\section{Relationship between clonal growth and soil physical factors}

The result showed that after flood overtopping, the number of adventitious buds exhibited a highly significant negative correlation with soil bulk density but significant and positive correlations with soil porosity and field capacity. The number of unearthed clonal ramets exhibited highly significant positive correlations with both soil moisture content and field capacity. The number of earthed clonal ramets exhibited a significant positive correlation with soil porosity. while the clonal ramet height growth rate 
exhibited highly significant positive and negative correlations with field capacity and soil bulk density, respectively (Table A4). The results showed that the changes of the numbers of adventitious buds, numbers of clonal ramets and the clonal ramet height growth rate were correlated with the changes of soil moisture content, soil bulk density, soil porosity, and field capacity before and after flooding overflow, the same soil physical factors before and after flood exerted different effects on the clone growth.
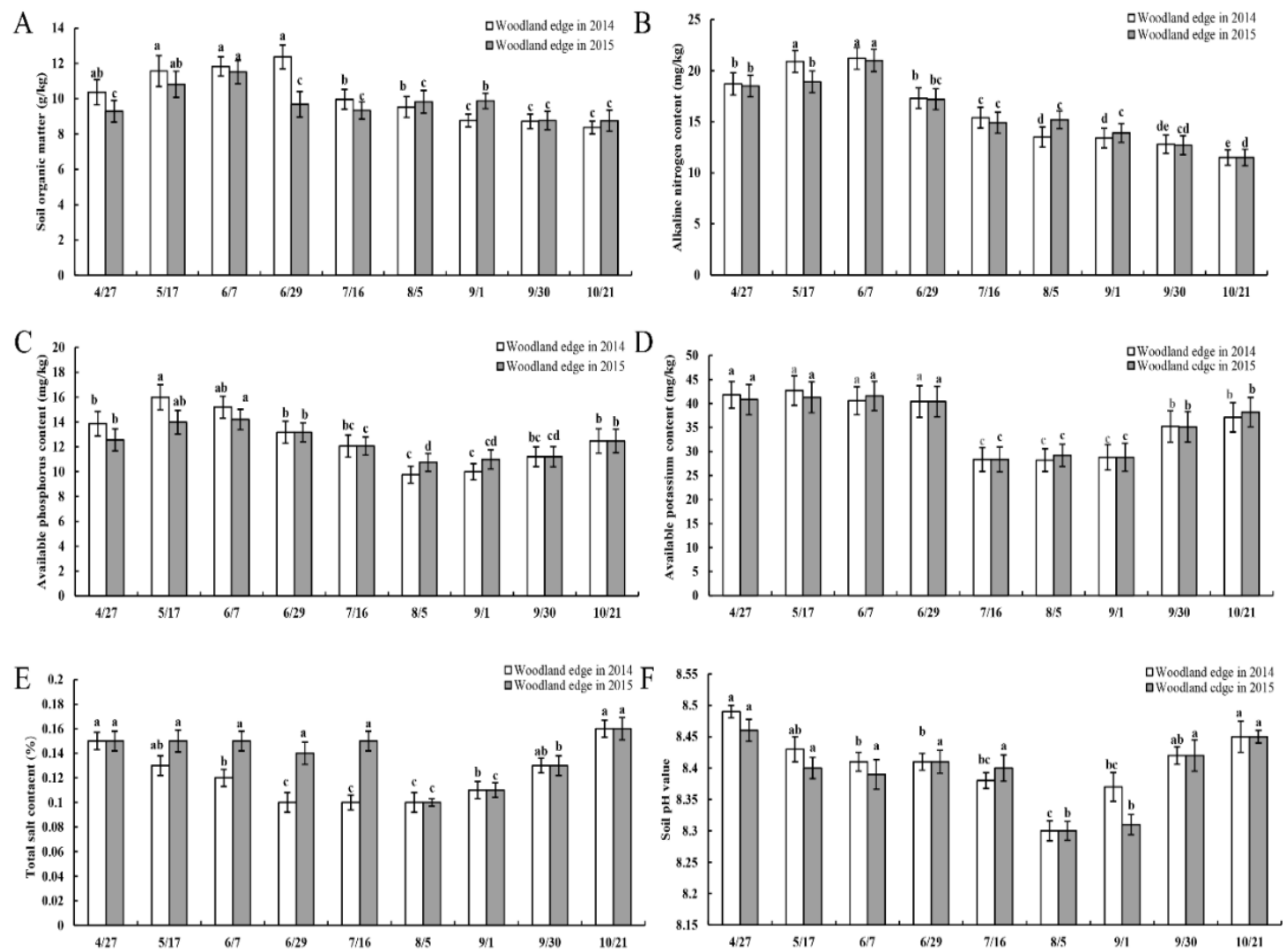

Figure 4. The dynamic change in soil chemistry factors before and after flood overtopping. (A) The content of soil organic matter, $(B)$ the content of the alkaline nitrogen, $(C)$ the content of soil available phosphorus, $(D)$ the content of soil available potassium, $(E)$ the content of total salt and $(F)$ the content of $p H$ values

\section{Relationship between clonal growth and soil chemical factors}

The correlation analysis results showed that the clone ramet height rate of increase before flood overtopping had a significant positive correlation with soil organic matter but a highly significant negative correlation with $\mathrm{pH}$ value. After flood overtopping, the number of adventitious buds had a significant positive correlation with both soil organic matter content and alkaline nitrogen but highly significant negative correlations with available phosphorus, available potassium, total salt and $\mathrm{pH}$ value. Meanwhile, the number of unearthed clonal ramets had a significant positive correlation with alkaline nitrogen, while the number of earthed clonal ramets had a highly significant negative correlation with available potassium. The rate of increase in ramet height had a significant negative correlation with total salt (Table A5), The results indicated that the 
changes of the numbers of adventitious buds, numbers of clonal ramets and the clonal ramet height growth rate were correlated with soil organic matter, alkaline nitrogen, available phosphorus, available potassium, total salt and $\mathrm{pH}$ value, the same soil chemical factors before and after flood had varying effects on the clone growth.

\section{Path analysis of soil physical factors on the clonal growth of Populus pruinosa}

On the basis of correlation analysis, further path analysis shows that before flood overtopping (from April to July), soil moisture content and field capacity were the main physical factors affecting the numbers of adventitious buds, numbers of unearthed or earthed clonal ramets, numbers of ramets per cluster, ramet height growth rate and basal growth rate; After flood overtopping (from August to October), soil porosity was the main physical factor affecting the numbers of adventitious buds, numbers of unearthed or earthed clonal ramets, numbers of ramets per cluster, ramet height growth rate (Table 1). These implied that soil moisture content and field water capacity were the main factors affecting the clonal growth of $P$. pruinosa before flood overtopping, and soil porosity was the main factors affecting the clonal growth of $P$. pruinosa after flooding overtopping.

\section{Path analysis of soil chemical factors on the clonal growth of Populus pruinosa}

Path analysis shows that before flooding overtopping, soil organic matter content and alkaline nitrogen were the main chemical factors affecting the numbers of adventitious buds, numbers of unearthed or earthed clonal ramets, numbers of ramets per cluster, ramet height growth rate and basal growth rate. After flood overtopping, available phosphorus and available potassium were the main chemical factors affecting the numbers of adventitious buds, numbers of unearthed or earthed clonal ramets, numbers of ramets per cluster, ramet height growth rate (Table 2). These implied that soil organic matter content and alkaline nitrogen were the main factors affecting the clonal growth of $P$. pruinosa before flood overtopping, and available phosphorus and available potassium were the main factors affecting the clonal growth of $P$. pruinosa after flood overtopping.

\section{Discussion}

Among soil physical factors, soil water is the main ecological factor influencing the growth and reproduction of plants. Plants adapt to the availability of water resources mainly through plant plasticity. When the availability of soil water is high, clonal plants grow to a high density, reach a large size, and exhibit strong clonal growth capacity that leads to a predictably large number of clonal offspring, high ramet fitness, and a low death risk (He, 2007). Several studies have demonstrated that the clonal growth of $P$. pruinosa was conducted only in the presence of $15 \%$ soil moisture content or higher, the number of adventitious buds and the number of earthed clonal ramets had significant positive correlation with soil moisture content (Zheng et al., 2016b). Our study revealed that before flood overtopping (from April to June), the rapid increase in the number of adventitious buds and the number of clonal ramets of $P$. pruinosa is the most vigorous stage of clone reproductions in a year, which is related to the biological characteristics and the gradual increase in temperature and surface temperature (Zheng et al., 2016a), path analysis showed that soil moisture content and field capacity were the main soil 
physical factors affecting the clonal growth of $P$. pruinosa. The soil moisture content in each period of this stages was over $15 \%$, and the field capacity remained above $30 \%$, which satisfied the water requirement of the clone growth of $P$. pruinosa at this stage. Remarkable, In the middle of July, the soil moisture content was the lowest before the flood overflows, the number of adventitious buds, the number of clonal ramets clones and the number of ramets per cluster were also significantly reduced, indicating that they were very sensitive to the change of soil moisture.

Our analysis also revealed that the high level of soil moisture content from April to June was related to the flood overtopping occurred in the previous year. Despite the significant decrease in soil water content in October after flood overtopping, field capacity exhibited no significant decline and remained constant through April of the next year. This result suggests that a high soil effective moisture content resulted from an increase in the underground water level and persistence of abundant water in the soil after flood overtopping. Therefore, water retained in the soil after flooding before the previous autumn replenished soil moisture for the following spring by storage of water through winter freezing. Subsequent spring thawing then released water to support the clonal growth of $P$. pruinosa from April to May. On the other hand, as the ground temperature and air temperature increased gradually from April to June, surface evaporation increased gradually, which promoted soil moisture to move from deeper layers to the $0-40-\mathrm{cm}$ soil layer, gradually increasing both soil moisture content and field capacity during the spring phase. The significance of this process is that it also leads to the migration of soil organic matter, alkaline nitrogen, available phosphorus, and available potassium to improve habitat quality. The improved habit in turn is more conducive to supporting increased numbers of adventitious buds and greater clone ramet growth. This shows that the flooding of forestland last year has an important effect on the clonal reproduction of $P$. pruinosa from April to June next year. From August to October after flood overtopping, the number of adventitious buds, the number of clonal ramets of $P$. pruinosa and the growth rate of clone ramets were obviously decreased, these changes were related to the gradual decrease of land surface temperature and air temperature at this stage (Zheng et al., 2016a). Our results showed that the change was significantly affected by the change of soil physical factors during the same period. The soil physical factors of forestland have larger changes compare with before the flood overtopping, the soil moisture content ranged from $25 \%$ to below $15 \%$, with gradual decreases in both field capacity and soil porosity and gradual increases in soil bulk density, they were positive or negative correlation with the number of adventitious buds, the number of unearthed/earthed clonal ramets and the growth rate of clone ramets, path analysis showed that soil porosity was the main factors affecting the clonal growth of $P$. pruinosa after flooding overtopping. Analysis suggested that after the forestland was flooded in late July, the forestland was in the state of water accumulation from August to September due to the large amount of overflowed flood, it will cause increased soil bulk density lead to the soil structure to tighten and soil porosity to decrease, both of which are disadvantageous to the adventitious bud formation of clonal ramets. This finding is consistent with the conclusion reached by Zhang et al. (2007) and Jing et al. (2013), suggesting that the high soil moisture content will lead to the increase of soil compactness, and the resistance to the growth of tiller buds of $P$. euphratica was larger, which is not conducive to the formation of clonal seedling of $P$. euphratica. The results suggested that the excessive and long flood. overtopping in forestland has certain inhibitory effect on the clonal growth of $P$. pruinosa. 
Table 1. The path analysis of clonal growth indexes and soil physical factors in 2014 and 2015

\begin{tabular}{|c|c|c|c|c|c|c|c|c|c|}
\hline \multirow[b]{3}{*}{ Index } & \multirow[b]{3}{*}{ Month } & \multicolumn{4}{|c|}{ Woodland edge in 2014} & \multicolumn{4}{|c|}{ Woodland edge in 2015} \\
\hline & & \multicolumn{4}{|c|}{ Direct effect } & \multicolumn{4}{|c|}{ Direct effect } \\
\hline & & Soil moisture content & Soil bulk density & Field capacity & Soil porosity & Soil moisture content & Soil bulk density & Field capacity & Soil porosity \\
\hline \multirow{2}{*}{ Unearthed ramets } & $4 \sim 7$ & -1.561 & -1.1232 & 0.4175 & 1.5158 & -0.4503 & 0.2314 & 0.8492 & -0.7132 \\
\hline & $8 \sim 10$ & 0.5934 & 0.0247 & -0.2705 & -0.1487 & 0.8303 & -0.4438 & 1.0506 & -1.262 \\
\hline \multirow{2}{*}{ Earthed ramets } & $4 \sim 7$ & 2.8241 & 1.5284 & -0.7358 & -2.389 & -0.488 & -0.4247 & 0.751 & 0.053 \\
\hline & $8 \sim 10$ & -0.6716 & -0.6854 & 0.6595 & 0.3647 & 0.0162 & -0.2727 & 0.1661 & 0.4518 \\
\hline \multirow{2}{*}{ Adventitious buds } & $4 \sim 7$ & 0.8731 & 0.0294 & -0.0386 & -0.1624 & -1.0779 & -1.0745 & 2.2182 & -0.0876 \\
\hline & $8 \sim 10$ & -0.7317 & -1.2084 & 0.0433 & 1.6095 & -0.5762 & -1.1502 & 0.0867 & 1.5251 \\
\hline \multirow{2}{*}{ Ramets per cluster } & $4 \sim 7$ & 1.6353 & 1.1283 & -0.9465 & -1.0542 & -0.1372 & -0.134 & -0.3361 & 0.7112 \\
\hline & $8 \sim 10$ & -0.8042 & -0.2821 & -0.7034 & 1.8477 & -1.8749 & -0.3819 & -2.1129 & 4.0415 \\
\hline \multirow{2}{*}{ Clone ramet height } & $4 \sim 7$ & 1.1674 & 0.2274 & -0.5493 & -0.1167 & -0.4713 & -0.9913 & 0.9105 & 0.771 \\
\hline & $8 \sim 10$ & -1.0058 & -1.3499 & 0.1188 & 1.731 & -0.788 & -1.2896 & 0.243 & 1.5408 \\
\hline \multirow{2}{*}{ Basal diameter } & $4 \sim 7$ & 3.1189 & 1.9932 & -0.8364 & -2.6403 & -1.8356 & -0.4446 & 1.9794 & -0.3363 \\
\hline & $8 \sim 10$ & 0.8534 & 0.3348 & 0.1005 & -0.2712 & 1.0988 & 0.3711 & 0.4042 & -0.7973 \\
\hline
\end{tabular}

Table 2. The path analysis of clonal growth indexes and soil chemical factors in 2014 and 2015

\begin{tabular}{|c|c|c|c|c|c|c|c|c|c|c|c|c|c|}
\hline \multirow[b]{3}{*}{ Index } & \multirow[b]{3}{*}{ Month } & \multicolumn{6}{|c|}{ Woodland edge in 2014} & \multicolumn{6}{|c|}{ Woodland edge in 2015} \\
\hline & & \multicolumn{6}{|c|}{ Direct effect } & \multicolumn{6}{|c|}{ Direct effect } \\
\hline & & $\begin{array}{l}\text { Alkaline } \\
\text { nitrogen }\end{array}$ & $\begin{array}{c}\text { Available } \\
\text { phosphorus }\end{array}$ & $\begin{array}{l}\text { Available } \\
\text { potassium }\end{array}$ & $\begin{array}{l}\text { Total salt } \\
\text { content }\end{array}$ & pH value & $\begin{array}{c}\text { Soil organic } \\
\text { matter }\end{array}$ & $\begin{array}{l}\text { Alkaline } \\
\text { nitrogen }\end{array}$ & $\begin{array}{c}\text { Available } \\
\text { phosphorus }\end{array}$ & $\begin{array}{l}\text { Available } \\
\text { potassium }\end{array}$ & $\begin{array}{c}\text { Total salt } \\
\text { content }\end{array}$ & pH value & $\begin{array}{c}\text { Soil organic } \\
\text { matter }\end{array}$ \\
\hline \multirow{2}{*}{ Unearthed ramets } & $4 \sim 7$ & 0.3934 & -0.0143 & -1.0423 & 0.922 & -0.2988 & 0.5959 & 19.7537 & 38.4471 & -22.9292 & 0.0289 & -4.4559 & -38.5662 \\
\hline & $8 \sim 10$ & 1.1028 & -0.7677 & 0.5053 & 1.2211 & -0.7739 & 0.1307 & -1.4196 & -3.461 & 5.5317 & 0.0932 & -2.0523 & 4.8764 \\
\hline \multirow{2}{*}{ Earthed ramets } & $4 \sim 7$ & 1.4751 & -1.6677 & -0.1188 & -0.123 & 0.0577 & 0.6388 & -15.7853 & -28.7587 & 18.2588 & 0.2381 & 3.2797 & 29.0582 \\
\hline & $8 \sim 10$ & -0.421 & 1.3944 & -1.0881 & -1.149 & 0.401 & -0.1493 & 8.6738 & 19.7736 & -36.8747 & -0.5142 & 12.8065 & -30.0733 \\
\hline \multirow{2}{*}{ Adventitious buds } & $4 \sim 7$ & 2.3372 & -1.9114 & -0.687 & 0.3751 & 0.081 & 1.007 & -22.0788 & -45.2123 & 27.2463 & -0.234 & 5.6132 & 44.8165 \\
\hline & $8 \sim 10$ & 0.3139 & 0.2457 & -0.7341 & 0.1799 & -0.2237 & 0.482 & -1.3648 & -5.0562 & 9.6097 & -0.0434 & -3.5602 & 7.953 \\
\hline \multirow{2}{*}{ Ramets per cluster } & $4 \sim 7$ & 0.6993 & -0.4714 & -0.5894 & -0.4281 & 0.2355 & 0.345 & -21.7366 & -42.7332 & 25.2295 & -0.5997 & 5.7702 & 42.771 \\
\hline & $8 \sim 10$ & -0.5239 & -0.3354 & 0.0726 & -0.086 & 0.3523 & 0.6321 & -16.3575 & -39.7764 & 74.907 & 0.2628 & -25.3393 & 60.7634 \\
\hline \multirow{2}{*}{ Clone ramet height } & $4 \sim 7$ & 0.8933 & -0.4259 & -1.7771 & 0.7254 & -0.2895 & 1.819 & -26.1817 & -50.621 & 30.7549 & -0.3377 & 6.3253 & 51.0733 \\
\hline & $8 \sim 10$ & -0.5476 & -0.1118 & -0.6908 & -0.3661 & 0.2714 & 0.4392 & 4.4945 & 8.39 & -15.0579 & -0.0371 & 4.6477 & -12.1749 \\
\hline \multirow{2}{*}{ Basal diameter } & $4 \sim 7$ & 1.0998 & -1.4355 & -0.2117 & -0.1761 & 0.3083 & 0.6802 & -26.2869 & -52.24 & 31.3363 & -0.7127 & 7.1231 & 51.6999 \\
\hline & $8 \sim 10$ & -1.1161 & -2.7277 & 1.3629 & -0.5975 & 1.3412 & -0.1433 & -3.8594 & -8.8175 & 14.7609 & -0.1122 & -4.2438 & 12.3232 \\
\hline
\end{tabular}

APPLIED ECOLOGY AND ENVIRONMENTAL RESEARCH 18(3):4791-4806.

http://www aloki.hu • ISSN 15891623 (Print) • ISSN 17850037 (Online)

DOI: http://dx.doi.org/10.15666/aeer/1803_47914806

(c) 2020, ALÖKI Kft., Budapest, Hungary 
Flooding also contributes to the heterogeneous distribution of soil nutrients, including that of belowground building blocks that affect the development of plant root systems and clonal organs and alter growth characteristics. Such factors further influence the spatial distribution pattern and clonal plasticity of the building blocks of the plant, the entire clonal plant, and even the entire population. For example, clonal plant size can change with changing soil nutrient availability, which would alter the biomass of both the population and its building blocks as measured by the average basal diameter, average plant height, and allocation of above ground biomass (Pan et al., 2005; Yue et al., 2002). As a specific example, with an increase in soil nitrogen content, the number of Phyllostachys praecox clonal population ramets, plant height, and base diameter were observed to clearly increase (Yue et al., 2002). However, with a decline in soil nutrient content, underground biomass as a proportion of total biomass was observed to increase (Shang, 2000; Yue et al., 2002), while the increase of the alkaline nitrogen and available potassium content in soil were observed to effectively promote increased numbers of adventitious buds (Zheng et al., 2016b, 2019).

Our study revealed that before flood overtopping (from April to June), the rapid increase in the number of adventitious buds and the number of clonal ramets of $P$. pruinosa were positive or negative correlation with the increase of soil organic matter, alkaline nitrogen, and available phosphorus, total salt remained below $0.2 \%$, and the decrease of $\mathrm{pH}$ value. Path analysis showed that soil organic matter content and alkaline nitrogen were the main factors affecting the clonal growth of $P$. pruinosa. At this stage, with gradually increasing ground temperature and air temperature, sufficient soil moisture content, gradual increased contents of soil organic matter, alkaline nitrogen and available phosphorus, elevated habitat nutrient quality to a higher level favoured an increase in the number of adventitious buds and clonal ramets, ramet height, and base diameter growth. From August to October after flood overtopping, the gradual decrease in the number of adventitious buds and the number of clonal ramets of $P$. pruinosa have closely relation with the gradual decrease of soil organic matter and alkaline nitrogen, the gradual increase of available phosphorus, available potassium and total salt. Among the six soil chemical factors, the content of available phosphorus and available potassium in soil were the main factors affecting the clonal growth of $P$. pruinosa in this stage. Obviously, the increased content of available phosphorus and available potassium in the forestland after the flood overtopping had certain inhibitory effect on the increase in the number of adventitious buds and clonal ramets, ramet height, and base diameter growth in this stage. Previous studies have noted that flood overtopping changes soil nutrients by bringing in topsoil partially composed of organic matter while inducing leaching and flushing that reduce the levels of organic matter within the 0$40 \mathrm{~cm}$ deep soil layer. Therefore, organic matter content after flood overtopping exhibited characteristics opposite to those observed before overtopping with a gradual reduction in the effects observed with increased soil depth (Zhou et al., 2010). We speculate that many factors contribute to the significant reductions of organic matter and alkaline nitrogen observed after flood overtopping. The reductions may result from nutrient consumption during the clonal growth process. However, these reductions may instead be due to leaching and flushing after flood overtopping. Both types of processes lead to the reduction of organic matter and alkaline nitrogen within the $0-60 \mathrm{~cm}$ soil depth layer, with a gradual decrease in organic matter and alkaline nitrogen and a gradual increase in available phosphorus, available potassium, total salt, and $\mathrm{pH}$. Regardless of mechanism, such changes contribute to observed decreases in the 
numbers of adventitious buds, earthed/unearthed clonal ramets, ramets per cluster, and rate of increase in clonal ramet height.

\section{Conclusion}

This study showed that flooded woodland was conducive to clonal growth of $\mathrm{P}$. pruinosa, but flood overtopping for too long led to increase soil bulk density, decrease soil porosity, decrease of soil organic matter and alkaline nitrogen content, and increased of soil salinity and PH value, all of which hindered clonal growth. Therefore, the future work should focus on the relationship between clone growth and flood overflow, the research will need to confirm flood volume and duration for ensuring normal post-flooding clonal growth in the current year. At the same time, water retained in the soil after flooding does not affect the clonal growth during the following spring from April to May. The scheme can guide forestland managers how to realize the natural regeneration of $P$. pruinosa forest scientifically by using the methods of artificial drainage and flood diversion for irrigation after forestland flood overtopping, these may be of great significance for exploiting the effective utilization of seasonal flooding in this arid area to promote the clonal reproduction of natural woodland plants.

Acknowledgements. This work was financially supported by the National Natural Sciences Foundation of China (U1803231, 31260072), Innovative team Building Plan for key areas of Xinjiang Production and Construction Corps (2018CB003).

\section{REFERENCES}

[1] Alpert, P. (1996): Nutrient sharing in natural clonal fragments of Fragaria chiloensis. - Journal of Ecology 84: 395-406.

[2] Bai, W., Hou, X., Wu, Z., Ren, W., Zhao, Q. (2019): Advances in studies on morphological plasticity of Leymus chinensis rhizome. - Pratacultural Science 36(3): 821-834.

[3] He, B., Li, G. Q., Gao, H. Y., Chen, W. H., Li, G., Qiao, W. L., Jb, N. (2007): A comparison study on the clonal growth of Hippophae rhamniodes L. subsp. Sinensis at different soil moisture condition. - Journal of Yunnan University 29: 101-107.

[4] Hodge, A. (2004): The plastic plant: root responses to heterogeneous supplies of nutrients. - New Phytol 162: 9-24.

[5] Ikegami, M., Whigham, D. F., Werger, M. J. A. (2007): Responses of rhizome length and ramet production to resource availability in the clonal sedge Scirpus olneyi A. Gray. - Plant Ecology 189: 247-259.

[6] Jing, J., Xia, Y. (2013): Impacts of soil type, water content and salinity on the root sucker occurrence mechanism of Populus euphratica. - Journal of Northeast Forestry University 41: 42-46.

[7] Li, Z. J., Jiao, P. P., Zhou, Z. L., Li, Q., Jq, L. (2012): Morphological and anatomical features of root sucker propagation of Populus pruinosa. - Chinese Bulletin of Botany 47(2): 133-140. DOI: 10.3724/SP.J.1259.2012.00133.

[8] Luo, X. G., Dong, M. (2002): Architectural plasticity in response to soil moisture in the stoloniferous herb, Duchesnea indica. - Acta Botanica Sinica 44: 97-100. 
[9] Pan, Q., Bai, Y., Han, X., Yang, J. (2005): Effects of nitrogen additions on a Leymus chinensis population in typical steppe of Inner Mongolia. - Acta Phytoecologica Sinica 29: 311-317.

[10] Ren, A. (1999): Effect of drought stress on clonal growth of Pennisetum centrasiaticum and Leymus Secalinus. - Journal of Desert Research 19: 30-34.

[11] Ren, M., Wei, C., Pei, Z. (2015): Influences of different vegetation types on soil parameters in degraded sandy lands of Songnen Plain. - Bulletin of Botanical Research 35: 765-771.

[12] Roiloa, S. R., Retuerto, R. (2006): Small-scale heterogeneity in soil quality influences photosynthetic efficiency and habitat selection in a clonal plant. - Annals of Botany 98: 1043-1052.

[13] Shang, B.-Q., Du, G.-Z., Liu, Z.-H. (2000): Clonal growth of Ligularia virgaurea: morphological responses to nutritional variation. - Acta Phytoecologica Sinica 24: 46-51.

[14] Silvertown, J. W. (1984): Introduction to plant population ecology. - Vegetatio 56: 86-86.

[15] Wei, C., Shen, G., Pei, Z. (2015): Effects of different plants cultivation on soil physical-chemical properties and fine root growth in saline-alkaline soil in Songnen Plain, Northeastern China. - Bulletin of Botanical Research 35(5): 759-764.

[16] Wu, F. P., Li, J. Q., Li, J. W., Cheng, C. L., Wang, X. H. (2008): The character tics of root suckers of Populus euphratica Oliv. in three habitats of Ejina oasis. - Acta Ecologica Sinica 28: 4703-4709.

[17] Yue, C., Wang, K., He, Q., Weng, F. (2002): Comparative research on clonal growth of Phyllostachys praecos in different conditions of soil nitrogen content. - Journal of Bamboo Research 21: 38-45.

[18] Zhang, D. Y., H. L. W. (2005): Preliminary study on the growth pattern of several clonal plants in desert zones of Xinjiang. - Arid Zone Research 22: 219-224.

[19] Zhang, H., Li, J., Li, J., Zhang, Y., Sun 1, Wu, P., Zhao, J. (2007): The reproductive phenological rhythm characteristics of Populus euphratica Oliv. Population in The Ejina Oasis of Inner Mongolia. - Journal of Inner Mongolia Agricultural University 28: 66-72.

[20] Zhao, Z. (2015): The growth of Populus Pruinosa clonal dynamics and its influencing factors. - Master Thesis, Tarim University, Alar.

[21] Zheng, Y., Jiao, P., Zhao, Z., Li, Z. (2016a): Clonal growth of Populus Pruinosa Schrenk and its role in the regeneration of riparian forests. - Ecological Engineering 94: 380-392.

[22] Zheng, Y., Zhang, X., Liang, J., Li, Z., Han, Z. (2016b): Clonal growth characteristics of the endangered species Populus euphratica Oliv and Populus pruinosa Schrenk. Acta Ecologica Sinica 36: 1331-1341.

[23] Zheng, Y., Zhai, J., Chen, J., Han, Z., Jiao, P., Li, Z. (2019): Seasonal variations of clonal propagation characteristics of Populus pruinosa Schrenk, organ nutrient and soil fertility, and their coupling associations in the forest and forest edges. - Bulletin of Botanical Research 39(3): 347-357.

[24] Zhou, B., Yang, H.-M., Hu, S.-J., Xiong, H.-G. (2010): Effect of river-flooding on soil physical-chemical properties and vegetation. - Arid Land Geography 33: 130136. 


\section{APPENDIX}

Table A1. Dynamic variation on the clonal growth of P. pruinosa

\begin{tabular}{|c|c|c|c|c|c|c|c|c|c|c|c|c|}
\hline \multirow[b]{2}{*}{ Month } & \multicolumn{2}{|c|}{ Adventitious bud } & \multicolumn{2}{|c|}{ Unearthed ramets } & \multicolumn{2}{|c|}{ Earthed ramets } & \multicolumn{2}{|c|}{ Clone ramets height } & \multicolumn{2}{|c|}{ Basal diameter } & \multicolumn{2}{|c|}{ Ramets per cluster } \\
\hline & $\begin{array}{c}\text { Woodland } \\
\text { edge in } 2014\end{array}$ & $\begin{array}{c}\text { Woodland } \\
\text { edge in } 2015\end{array}$ & $\begin{array}{c}\text { Woodland } \\
\text { edge in } 2014\end{array}$ & \begin{tabular}{|} 
Woodland \\
edge in 2015
\end{tabular} & $\begin{array}{c}\text { Woodland } \\
\text { edge in } 2014\end{array}$ & $\begin{array}{c}\text { Woodland } \\
\text { edge in } 2015\end{array}$ & $\begin{array}{c}\text { Woodland edge } \\
\text { in } 2014\end{array}$ & $\begin{array}{l}\text { Woodland edge } \\
\text { in } 2015\end{array}$ & $\begin{array}{l}\text { Woodland edge } \\
\text { in } 2014\end{array}$ & $\begin{array}{l}\text { Woodland edge } \\
\text { in } 2015\end{array}$ & $\begin{array}{c}\text { Woodland } \\
\text { edge in } 2014\end{array}$ & $\begin{array}{c}\text { Woodland } \\
\text { edge in } 2015\end{array}$ \\
\hline $4 / 27$ & $28.2 \pm 1.16 \mathrm{c}$ & $17 \pm 1.67 \mathrm{~b}$ & $1.7 \pm 0.09 \mathrm{~b}$ & $5.5 \pm 0.256 \mathrm{a}$ & $3.4 \pm 0.39 \mathrm{~d}$ & $3.3 \pm 0.42 \mathrm{c}$ & $0.490 \pm 0.04 \mathrm{c}$ & $0.260 \pm 0.07 \mathrm{~d}$ & $0.005 \pm 0.0008 \mathrm{e}$ & $0.0015 \pm 0.0002 \mathrm{c}$ & $3.5 \pm 0.56 \mathrm{~g}$ & $3 \pm 0.66 \mathrm{~g}$ \\
\hline $5 / 17$ & $35 \pm 1.59 b c$ & $16.5 \pm 2.12 b$ & $3 \pm 0.24 \mathrm{a}$ & $2.6 \pm 0.235 b$ & $3.5 \pm 0.28 \mathrm{~d}$ & $7 \pm 0.32 \mathrm{~b}$ & $1.390 \pm 0.06 \mathrm{~b}$ & $1.360 \pm 0.12 \mathrm{~b}$ & $0.005 \pm 0.0003 \mathrm{e}$ & $0.0020 \pm 0.0006 \mathrm{~b}$ & $7 \pm 0.64 \mathrm{e}$ & $5 \pm 0.52 \mathrm{f}$ \\
\hline $6 / 7$ & $70 \pm 3.02 \mathrm{a}$ & $22.5 \pm 3.15 \mathrm{a}$ & $1.7 \pm 0.16 \mathrm{~b}$ & $0.6 \pm 0.09 \mathrm{de}$ & $8.1 \pm 0.24 \mathrm{a}$ & $5.5 \pm 0.29 b \mathrm{c}$ & $2.20 \pm 0.003 \mathrm{a}$ & $1.695 \pm 0.13 \mathrm{a}$ & $0.009 \pm 0.0002 \mathrm{~b}$ & $0.0025 \pm 0.0006 \mathrm{a}$ & $10.6 \pm 0.95 \mathrm{c}$ & $9.2 \pm 1.01 \mathrm{c}$ \\
\hline $6 / 29$ & $41 \pm 1.87 \mathrm{~b}$ & $10.6 \pm 1.68 \mathrm{bc}$ & $0.4 \pm 0.07 \mathrm{~cd}$ & $2 \pm 0.12 \mathrm{c}$ & $6.8 \pm 0.18 \mathrm{~b}$ & $9.2 \pm 0.21 \mathrm{a}$ & $1.827 \pm 0.12 \mathrm{ab}$ & $0.865 \pm 0.15 \mathrm{c}$ & $0.010 \pm 0.0007 \mathrm{a}$ & $0.0025 \pm 0.0006 \mathrm{a}$ & $11.8 \pm 0.79 b$ & $11 \pm 0.82 \mathrm{~b}$ \\
\hline $7 / 16$ & $13.6 \pm 0.98 \mathrm{~d}$ & $9 \pm 1.52 \mathrm{bc}$ & $0.8 \pm 0.11 \mathrm{c}$ & $0.3 \pm 0.08 \mathrm{e}$ & $3.8 \pm 0.17 \mathrm{~d}$ & $3.7 \pm 0.26 \mathrm{c}$ & $1.008 \pm 0.06 \mathrm{bc}$ & $0.625 \pm 0.1 \mathrm{~cd}$ & $0.008 \pm 0.0005 \mathrm{c}$ & $0.0025 \pm 0.0004 \mathrm{a}$ & $12.6 \pm 0.38 \mathrm{a}$ & $11.8 \pm 0.44 \mathrm{a}$ \\
\hline $8 / 5$ & $30 \pm 1.96 \mathrm{c}$ & $18.7 \pm 2.36 \mathrm{ab}$ & $0.7 \pm 0.08 \mathrm{c}$ & $1.1 \pm 0.14 \mathrm{~d}$ & $6.1 \pm 0.36 \mathrm{bc}$ & $5.4 \pm 0.28 \mathrm{bc}$ & $0.577 \pm 0.009 \mathrm{c}$ & $0.520 \pm 0.09 \mathrm{~cd}$ & $0.006 \pm 0.0004 \mathrm{~d}$ & $0.0020 \pm 0.0002 \mathrm{~b}$ & $8.8 \pm 0.55 \mathrm{~d}$ & $8.4 \pm 0.68 \mathrm{~d}$ \\
\hline $9 / 1$ & $21 \pm 2.03 \mathrm{~cd}$ & $15 \pm 1.23 \mathrm{~b}$ & $0.6 \pm 0.12 \mathrm{c}$ & $1.1 \pm 0.08 \mathrm{~d}$ & $6.2 \pm 0.29 \mathrm{bc}$ & $4.9 \pm 0.34 \mathrm{bc}$ & $0.328 \pm 0.045 \mathrm{~cd}$ & $0.217 \pm 0.04 \mathrm{~d}$ & $0.005 \pm 0.0005 \mathrm{e}$ & $0.0017 \pm 0.0002 \mathrm{c}$ & $6 \pm 0.85 \mathrm{f}$ & $7.1 \pm 0.96 \mathrm{e}$ \\
\hline $9 / 30$ & $7.8 \pm 0.68 \mathrm{de}$ & $7.8 \pm 1.42 \mathrm{bc}$ & $0.7 \pm 0.01 \mathrm{c}$ & $0.6 \pm 0.05 \mathrm{de}$ & $5.0 \pm 0.42 \mathrm{c}$ & $3.9 \pm 0.35 \mathrm{c}$ & $0.113 \pm 0.002 \mathrm{~d}$ & $0.143 \pm 0.001 \mathrm{~d}$ & $0.005 \pm 0.0005 \mathrm{e}$ & $0.0015 \pm 0.0002 \mathrm{c}$ & $6.2 \pm 0.34 \mathrm{f}$ & $6.8 \pm 0.26 \mathrm{e}$ \\
\hline $10 / 21$ & $0.5 \pm 0.13 \mathrm{e}$ & $1.5 \pm 0.14 \mathrm{c}$ & $0.3 \pm 0.09 \mathrm{~d}$ & $0.1 \pm 0.009 \mathrm{e}$ & $4.8 \pm 0.39 \mathrm{c}$ & $2.6 \pm 0.34 \mathrm{~d}$ & $0.025 \pm 0.012 \mathrm{e}$ & $0.025 \pm 0.003 \mathrm{e}$ & $0.003 \pm 0.0001 \mathrm{f}$ & $0.0008 \pm 0.0002 \mathrm{~d}$ & $6.2 \pm 0.12 \mathrm{f}$ & $6.8 \pm 0.09 \mathrm{e}$ \\
\hline
\end{tabular}

Table A2. The dynamic change in soil physical factors

\begin{tabular}{|c|c|c|c|c|c|c|c|c|}
\hline \multirow[b]{2}{*}{ Month } & \multicolumn{2}{|c|}{ Soil moisture content } & \multicolumn{2}{|c|}{ Field capacity } & \multicolumn{2}{|c|}{ Soil bulk density } & \multicolumn{2}{|c|}{ Soil porosity } \\
\hline & $\begin{array}{c}\text { Woodland edge in } \\
2014\end{array}$ & $\begin{array}{c}\text { Woodland edge in } \\
2015\end{array}$ & $\begin{array}{c}\text { Woodland edge in } \\
2014\end{array}$ & $\begin{array}{c}\text { Woodland edge in } \\
2015 \\
\end{array}$ & $\begin{array}{l}\text { Woodland edge } \\
\text { in } 2014\end{array}$ & $\begin{array}{l}\text { Woodland edge } \\
\text { in } 2015\end{array}$ & $\begin{array}{l}\text { Woodland edge } \\
\text { in } 2014\end{array}$ & $\begin{array}{l}\text { Woodland edge } \\
\text { in } 2015\end{array}$ \\
\hline $4 / 27$ & $19.25 \pm 1.362 \mathrm{e}$ & $21.8 \pm 1.71 \mathrm{~b}$ & $33.67 \pm 2.12 \mathrm{ab}$ & $32.67 \pm 1.52 \mathrm{ab}$ & $1.32 \pm 0.03 \mathrm{~b}$ & $1.33 \pm 0.0024 \mathrm{a}$ & $48.04 \pm 1.81 \mathrm{e}$ & $47.84 \pm 1.43 \mathrm{~b}$ \\
\hline $5 / 17$ & $22.09 \pm 1.275 \mathrm{~d}$ & $21.55 \pm 1.65 \mathrm{~b}$ & $32.64 \pm 1.23 \mathrm{c}$ & $32.64 \pm 1.59 \mathrm{a}$ & $1.29 \pm 0.0031 \mathrm{~d}$ & $1.31 \pm 0.005 \mathrm{ab}$ & $50.74 \pm 2.05 \mathrm{~cd}$ & $50.54 \pm 1.78 \mathrm{ab}$ \\
\hline $6 / 7$ & $23.15 \pm 1.143 \mathrm{c}$ & $20.3 \pm 1.52 \mathrm{bc}$ & $31.77 \pm 1.96 \mathrm{~d}$ & $32.77 \pm 1.46 \mathrm{ab}$ & $1.31 \pm 0.0018 \mathrm{c}$ & $1.31 \pm 0.0014 \mathrm{ab}$ & $51.94 \pm 1.77 \mathrm{a}$ & $51.75 \pm 1.63 \mathrm{a}$ \\
\hline $6 / 29$ & $24.13 \pm 1.33 \mathrm{bc}$ & $17.81 \pm 1.39 \mathrm{c}$ & $33.78 \pm 1.65 \mathrm{a}$ & $31.71 \pm 1.84 \mathrm{~b}$ & $1.3 \pm 0.0061 \mathrm{~cd}$ & $1.30 \pm 0.0081 \mathrm{ab}$ & $51.74 \pm 1.65 \mathrm{ab}$ & $51.55 \pm 1.71 \mathrm{a}$ \\
\hline $7 / 16$ & $19.3 \pm 1.65 \mathrm{e}$ & $16.75 \pm 1.33 \mathrm{c}$ & $30.28 \pm 1.39 \mathrm{e}$ & $30.28 \pm 1.62 \mathrm{c}$ & $1.36 \pm 0.0041 \mathrm{a}$ & $1.32 \pm 0.0054 \mathrm{a}$ & $50.06 \pm 1.68 \mathrm{~cd}$ & $50.87 \pm 1.465$ a \\
\hline $8 / 5$ & $28 \pm 1.621 \mathrm{a}$ & $26 \pm 1.49 \mathrm{a}$ & $33.81 \pm 1.06 \mathrm{a}$ & $33.42 \pm 1.82 \mathrm{a}$ & $1.29 \pm 0.0071 \mathrm{~d}$ & $1.29 \pm 0.0093 \mathrm{~b}$ & $51.73 \pm 1.78 \mathrm{ab}$ & $51.54 \pm 1.82 \mathrm{a}$ \\
\hline $9 / 1$ & $27 \pm 1.47 \mathrm{a}$ & $25 \pm 1.73 \mathrm{a}$ & $34.2 \pm 1.31 \mathrm{a}$ & $33.20 \pm 1.04 \mathrm{a}$ & $1.3 \pm 0.0054 \mathrm{~cd}$ & $1.30 \pm 0.0081 \mathrm{~b}$ & $50.89 \pm 1.75 \mathrm{bc}$ & $50.70 \pm 2.278 \mathrm{a}$ \\
\hline $9 / 30$ & $24.4 \pm 1.16 \mathrm{~b}$ & $22.9 \pm 1.59 \mathrm{ab}$ & $32.85 \pm 1.703 \mathrm{bc}$ & $32.49 \pm 1.98 \mathrm{ab}$ & $1.32 \pm 0.0024 \mathrm{~b}$ & $1.32 \pm 0.0022 \mathrm{a}$ & $49.91 \pm 1.82 \mathrm{~d}$ & $49.72 \pm 2.03 \mathrm{ab}$ \\
\hline $10 / 21$ & $12.24 \pm 1.35 \mathrm{f}$ & $13.9 \pm 1.42 \mathrm{~d}$ & $32.37 \pm 1.61 \mathrm{~cd}$ & $32.27 \pm 1.83 \mathrm{ab}$ & $1.35 \pm 0.002 \mathrm{ab}$ & $1.34 \pm 0.0032 \mathrm{a}$ & $47.78 \pm 1.77 \mathrm{e}$ & $47.59 \pm 2.172 \mathrm{~b}$ \\
\hline
\end{tabular}

APPLIED ECOLOGY AND ENVIRONMENTAL RESEARCH 18(3):4791-4806.

http://www.aloki.hu • ISSN 15891623 (Print) • ISSN 17850037 (Online)

DOI: http://dx.doi.org/10.15666/aeer/1803_47914806

(c) 2020, ALÖKI Kft., Budapest, Hungary 
Table A3. The dynamic change in soil chemistry factors

\begin{tabular}{|c|c|c|c|c|c|c|c|c|c|c|c|c|}
\hline \multirow[b]{2}{*}{ Month } & \multicolumn{2}{|c|}{ Soil organic matter } & \multicolumn{2}{|c|}{ Alkaline nitrogen } & \multicolumn{2}{|c|}{ Available phosphorus } & \multicolumn{2}{|c|}{ Available potassium } & \multicolumn{2}{|c|}{ Total salt content } & \multicolumn{2}{|c|}{ pH value } \\
\hline & $\begin{array}{c}\text { Woodland } \\
\text { edge in } 2014\end{array}$ & $\begin{array}{c}\text { Woodland } \\
\text { edge in } 2015\end{array}$ & $\begin{array}{c}\text { Woodland } \\
\text { edge in } 2014\end{array}$ & $\begin{array}{c}\text { Woodland } \\
\text { edge in } 2015\end{array}$ & $\begin{array}{c}\text { Woodland } \\
\text { edge in } 2014\end{array}$ & $\begin{array}{l}\text { Woodland edge } \\
\text { in } 2015\end{array}$ & $\begin{array}{l}\text { Woodland edge } \\
\text { in } 2014\end{array}$ & $\begin{array}{l}\text { Woodland edge } \\
\text { in } 2015\end{array}$ & $\begin{array}{c}\text { Woodland } \\
\text { edge in } 2014\end{array}$ & $\begin{array}{c}\text { Woodland } \\
\text { edge in } 2015\end{array}$ & $\begin{array}{c}\text { Woodland } \\
\text { edge in } 2014\end{array}$ & \begin{tabular}{|c|} 
Woodland \\
edge in 2015
\end{tabular} \\
\hline $4 / 27$ & $10.37 \pm 0.71 \mathrm{ab}$ & $9.29 \pm 0.61 \mathrm{c}$ & $18.7 \pm 1.08 \mathrm{~b}$ & $18.5 \pm 1.06 \mathrm{~b}$ & $13.86 \pm 0.98 \mathrm{~b}$ & $12.56 \pm 0.89 \mathrm{~b}$ & $41.8 \pm 2.78 \mathrm{a}$ & $40.8 \pm 3.16 \mathrm{a}$ & $0.15 \pm 0.007 \mathrm{a}$ & $0.15 \pm 0.008 \mathrm{a}$ & $8.49 \pm 0.01 \mathrm{a}$ & $8.46 \pm 0.018 \mathrm{a}$ \\
\hline $5 / 17$ & $11.57 \pm 0.88 \mathrm{a}$ & $10.82 \pm 0.74 \mathrm{ab}$ & $20.9 \pm 1.07 \mathrm{a}$ & $18.9 \pm 1.06 \mathrm{~b}$ & $15.99 \pm 1.01 \mathrm{a}$ & $13.98 \pm 0.95 \mathrm{ab}$ & $42.67 \pm 3.06 \mathrm{a}$ & $41.27 \pm 3.21 \mathrm{a}$ & $0.13 \pm 0.008 \mathrm{ab}$ & $0.15 \pm 0.009 \mathrm{a}$ & $8.43 \pm 0.02 \mathrm{ab}$ & $8.4 \pm 0.017 \mathrm{a}$ \\
\hline $6 / 7$ & $11.83 \pm 0.54 \mathrm{a}$ & $11.51 \pm 0.66 \mathrm{a}$ & $21.2 \pm 1.06 \mathrm{a}$ & $21 \pm 1.08 \mathrm{a}$ & $15.2 \pm 0.88 \mathrm{ab}$ & $14.2 \pm 0.82 \mathrm{a}$ & $40.56 \pm 2.91 \mathrm{a}$ & $41.56 \pm 3.06 \mathrm{a}$ & $0.12 \pm 0.007 \mathrm{~b}$ & $0.15 \pm 0.008 \mathrm{a}$ & $8.41 \pm 0.015 b$ & $8.39 \pm 0.024 \mathrm{a}$ \\
\hline $6 / 29$ & $12.37 \pm 0.68 \mathrm{a}$ & $9.69 \pm 0.72 \mathrm{c}$ & $17.3 \pm 1.01 \mathrm{~b}$ & $17.2 \pm 1.02 b c$ & $13.17 \pm 0.88 \mathrm{~b}$ & $13.17 \pm 0.76 \mathrm{~b}$ & $40.4 \pm 3.29 \mathrm{a}$ & $40.4 \pm 3.17 \mathrm{a}$ & $0.1 \pm 0.008 \mathrm{c}$ & $0.14 \pm 0.009 \mathrm{a}$ & $8.41 \pm 0.013 b$ & $8.41 \pm 0.018 \mathrm{a}$ \\
\hline $7 / 16$ & $9.97 \pm 0.56 \mathrm{~b}$ & $9.34 \pm 0.49 \mathrm{c}$ & $15.4 \pm 1.02 \mathrm{c}$ & $14.9 \pm 1.03 \mathrm{c}$ & $12.06 \pm 0.89 \mathrm{bc}$ & $12.06 \pm 0.73 \mathrm{c}$ & $28.33 \pm 2.50 \mathrm{c}$ & $28.33 \pm 2.58 \mathrm{c}$ & $0.1 \pm 0.006 \mathrm{c}$ & $0.15 \pm 0.008 \mathrm{a}$ & $8.38 \pm 0.01 \mathrm{bc}$ & $8.4 \pm 0.021 \mathrm{a}$ \\
\hline $8 / 5$ & $9.53 \pm 0.59 \mathrm{~b}$ & $9.83 \pm 0.64 \mathrm{c}$ & $13.5 \pm 0.98 \mathrm{~d}$ & $15.2 \pm 0.87 \mathrm{c}$ & $9.76 \pm 0.68 \mathrm{c}$ & $10.75 \pm 0.72 \mathrm{~d}$ & $28.2 \pm 2.37 \mathrm{c}$ & $29.2 \pm 2.29 \mathrm{c}$ & $0.1 \pm 0.008 \mathrm{c}$ & $0.10 \pm 0.003 \mathrm{c}$ & $8.3 \pm 0.016 \mathrm{c}$ & $8.3 \pm 0.015 b$ \\
\hline $9 / 1$ & $8.77 \pm 0.36 \mathrm{c}$ & $9.88 \pm 0.44 \mathrm{~b}$ & $13.4 \pm 0.96 \mathrm{~d}$ & $13.9 \pm 0.92 \mathrm{c}$ & $9.99 \pm 0.65 \mathrm{c}$ & $10.99 \pm 0.78 \mathrm{~cd}$ & $28.8 \pm 2.65 \mathrm{c}$ & $28.8 \pm 2.90 \mathrm{c}$ & $0.11 \pm 0.007 \mathrm{~b}$ & $0.11 \pm 0.006 \mathrm{c}$ & $8.37 \pm 0.023 \mathrm{bc}$ & $8.31 \pm 0.016 \mathrm{~b}$ \\
\hline $9 / 30$ & $8.72 \pm 0.41 \mathrm{c}$ & $8.77 \pm 0.52 \mathrm{c}$ & $12.8 \pm 0.89 \mathrm{de}$ & $12.7 \pm 0.93 \mathrm{~cd}$ & $11.2 \pm 0.79 \mathrm{bc}$ & $11.2 \pm 0.82 \mathrm{~cd}$ & $35.2 \pm 3.29 \mathrm{~b}$ & $35.12 \pm 3.17 \mathrm{~b}$ & $0.13 \pm 0.006 \mathrm{ab}$ & $0.13 \pm 0.008 b$ & $8.42 \pm 0.014 \mathrm{ab}$ & $8.42 \pm 0.025 \mathrm{a}$ \\
\hline $10 / 21$ & $8.37 \pm 0.36 \mathrm{c}$ & $8.76 \pm 0.6 \mathrm{c}$ & $11.5 \pm 0.75 \mathrm{e}$ & $11.5 \pm 0.81 \mathrm{~d}$ & $12.47 \pm 0.99 \mathrm{~b}$ & $12.47 \pm 0.94 \mathrm{~b}$ & $37.1 \pm 3.07 \mathrm{~b}$ & $38.2 \pm 3.05 \mathrm{~b}$ & $0.16 \pm 0.007 \mathrm{a}$ & $0.16 \pm 0.009 \mathrm{a}$ & $8.45 \pm 0.025 \mathrm{a}$ & $8.45 \pm 0.01 \mathrm{a}$ \\
\hline
\end{tabular}

Table A4. The correlation analysis between clonal growth indexes and soil physical factors

\begin{tabular}{|c|c|c|c|c|c|c|c|c|c|}
\hline \multirow[b]{2}{*}{ Index } & \multirow[b]{2}{*}{ Month } & \multicolumn{4}{|c|}{ Woodland edge in 2014} & \multicolumn{4}{|c|}{ Woodland edge in 2015} \\
\hline & & $\begin{array}{l}\text { Soil moisture } \\
\text { content }\end{array}$ & $\begin{array}{c}\text { Soil bulk } \\
\text { density }\end{array}$ & Soil porosity & Field capacity & $\begin{array}{l}\text { Soil moisture } \\
\text { content }\end{array}$ & Soil bulk density & Soil porosity & Field capacity \\
\hline \multirow{2}{*}{ Numbers of adventitious bud } & $4-7$ & 0.57 & 0.06 & -0.8 & 0.71 & 0.58 & 0.37 & 0.36 & $0.89 *$ \\
\hline & $8-10$ & 0.85 & $-0.96 * *$ & $0.89 *$ & $0.95^{*}$ & $0.92 *$ & $-0.99 * *$ & $0.98 * *$ & $0.98 * *$ \\
\hline \multirow{2}{*}{ Numbers of unearthed ramets } & $4-7$ & -0.40 & -0.32 & -0.49 & -0.23 & 0.51 & 0.81 & $-0.97 * *$ & 0.14 \\
\hline & $8-10$ & $0.96 * *$ & -0.86 & 0.67 & $0.89 *$ & $0.96^{*}$ & $-0.98 * *$ & $0.97 * *$ & $0.95^{*}$ \\
\hline \multirow{2}{*}{ Numbers of earthed ramets } & $4-7$ & 0.76 & 0.05 & -0.43 & 0.79 & -0.80 & $-0.94 *$ & 0.75 & -0.79 \\
\hline & $8-10$ & 0.68 & -0.83 & $0.95^{*}$ & 0.79 & $0.96^{*}$ & $-0.99 * *$ & $0.99 * *$ & $0.96 * *$ \\
\hline \multirow{2}{*}{ Numbers of ramets per cluster } & $4-7$ & $0.98 * *$ & -0.39 & -0.27 & $0.95^{*}$ & $-0.90 *$ & $-0.88^{*}$ & $0.90^{*}$ & -0.63 \\
\hline & $8-10$ & 0.47 & -0.63 & 0.40 & 0.65 & 0.60 & 0.80 & 0.76 & 0.83 \\
\hline \multirow{2}{*}{ Clone ramets height } & $4-7$ & $0.92 *$ & -0.41 & -0.59 & $0.98^{* *}$ & -0.10 & -0.59 & 0.81 & 0.24 \\
\hline & $8-10$ & 0.77 & $-0.91 *$ & 0.81 & $0.90 *$ & 0.80 & $-0.92 *$ & $0.90^{*}$ & $0.90 *$ \\
\hline \multirow{2}{*}{ Basal diameter } & $4-7$ & 0.71 & 0.06 & 0.19 & 0.59 & -0.77 & $-0.90 *$ & $0.98 * *$ & -0.45 \\
\hline & $8-10$ & 0.20 & -0.46 & 0.46 & 0.44 & $0.97 * *$ & $-0.97 * *$ & $0.99 * *$ & $0.90^{*}$ \\
\hline
\end{tabular}

$* \mathrm{P}<0.05, * * \mathrm{P}<0.01$ 